\title{
Growth and yield of pearl millet and chickpea as influenced by different sources and doses of organic manure under pearl millet-chickpea cropping system
}

\author{
M.F. HUSAIN*, MD. SHAMIM ${ }^{1}$ AND G.S. PARIHAR ${ }^{1}$ \\ Regional Research Station, Kalai, ALIGARH (U.P.) INDIA \\ (Email : mfhusain15@gmail.com)
}

\begin{abstract}
An experiment was laidout during three years from 2009-10 to 2011-12 at Regional Research Station, Kali, Aligarh, C.S. Azad university of Agriculture and Technology, Kanpur. The main objective was to findout the suitable organic source for enriching soil health, increasing grain yield of pearl millet and residual effect of applied organic sources on chickpea yield under pearl millet-chickpea cropping system. eight organic sources i.e., control, $2.5 \mathrm{t} \mathrm{FYM/ha,} 5.0 \mathrm{t} \mathrm{FYM/ha,} 7.5 \mathrm{t} \mathrm{FYM/ha,} 1.0 \mathrm{t}$ vermicompost/ha, $2.0 \mathrm{t}$ vermicompost/ha, $3.0 \mathrm{t}$ vermicompost/ha and $2.5 \mathrm{t} \mathrm{FYM}+1.0 \mathrm{t}$ vermicompost/ha were tested under pearl millet-chickpea cropping system. the pooled results of three years displayed that the application of $7.5 \mathrm{tFYM} / \mathrm{ha}$ gave significantly higher grain yield of pearl millet $(1912 \mathrm{~kg} / \mathrm{ha})$. The lowest grain yield of pearl millet recorded at control $(1204 \mathrm{~kg} / \mathrm{ha})$. Significantly maximum seed yield of chickpea was recorded under residual effect of $7.5 \mathrm{t} \mathrm{FYM} / \mathrm{ha}$ by $1376 \mathrm{~kg} / \mathrm{ha}$, while lowest yield noted at control (703 kg/ha). Application of $7.5 \mathrm{t} \mathrm{FYM/ha} \mathrm{gave} \mathrm{higher} \mathrm{pearl} \mathrm{millet} \mathrm{equivalent} \mathrm{yield} \mathrm{(6161} \mathrm{kg/ha),} \mathrm{net} \mathrm{return} \mathrm{(Rs.} \mathrm{31971/ha)}$ and BCR (1:4.48) in comparison to other tested source of organic manure.
\end{abstract}

Key Words : Inhabiting, Sodic soils, Soil profile, Staple cereal, Vermicompost

View Point Article : Husain, M.F., Shamim, Md. and Parihar, G. S. (2017). Growth and yield of pearl millet and chickpea as influenced by different sources and doses of organic manure under pearl millet-chickpea cropping system. Internat. J. agric. Sci., 13 (2) : $360-364$, DOI:10.15740/HAS/IJAS/13.2/360-364.

Article History : Received : 03.03.2017; Revised : 30.04.2017; Accepted : 14.05.2017

\footnotetext{
* Author for correspondence:

${ }^{1}$ C.S. AZAD University of Agriculture and Technology, KANPUR (U.P.) INDIA
} 